\title{
The Produced Gender Perception through the Political Ideologies in Turkey: A Review on the Twitter Posts
}

\author{
Türkiye'de Siyasal İdeolojiler Yoluyla Üretilen Toplumsal Cinsiyet Algısı: \\ Twitter Yorumları Üzerinden Bir İnceleme
}

\begin{abstract}
Nuriye ÇELIKK *
Abstract: The theory of feminism is translated into an ideological phenomenon that begins with women's demand for equal rights with men and defines women's individuality. Like any grand theory (all social theories in macro level), it exhibits ideological qualities and it inevitably interacts with other ideologies. There is a never-ending conflict between conservative ideology and feminism. In Turkey, there is a distinction between rising conservatism and feminism from the point of view definitions of family and women that arose from religious and cultural perspectives. This study applied content analysis to comments on video that aimed to prevent violence against women and published on the presidential twitter page. As a result of the analysis, it was found that those who wrote supporting comments did not support the conservative party but found the video correct; it was seen that those who wrote critical comments supported the relevant political party and think the feminism is damaging the conservative ideology. Another result of this study is women made the most criticism of feminism.
\end{abstract}

Keywords: Feminism, Conservative Discourse, Social Gender, Violence

$\ddot{\boldsymbol{O}}_{\boldsymbol{z} \text { : }}$ Feminizm teorisi kadınların erkeklerle eşit haklara sahip olma talebiyle başlayan ve kadınların bireyselliklerini tanımlayan ideolojik bir olguya çevrilmiş durumdadır. Her tür grand (makro boyuttaki tüm sosyal teoriler) teori gibi ideolojik nitelikler sergiler ve diğer ideolojilerle etkileşim içerisine girmesi kaçınılmazdır. Muhafazakar ideoloji ve feminizm arasında hiç bitmeyen bir çatışma vardır. Türkiye'de, artan muhafazakarlık ile feminizm arasında ailenin ve kadınların dini ve kültürel açıdan ortaya çıkan tanımları açısından bir ayrım bulunmaktadır. Bu çalışma, kadına yönelik şiddeti önlemeyi amaçlayan ve Cumhurbaşkanlığı Twitter sayfasında yayınlanan bir video hakkındaki yorumlara içerik analizi uygulanmıştır. İçerik analizi kullanıcıların birbirine verdiği kişisel yanıtları ve argo ifade içeren söylemleri çalışma dışında bırakmıştır. Yapılan analiz sonucunda iki ayrı kutup olarak destekleyici ve eleştirel yorumlar tespit edilmiştir. Destekleyici yorumların videoyu yayınlayan siyasi partiyi desteklemediği fakat şiddete karşı birleştikleri görülmüştür. Öte yandan eleştirel yorum yapanların ilgili siyasi partiyi destekledikleri fakat feminizmin muhafazakarlığa zarar verdiği noktasında birleştikleri görülmüştür. Feminizm eleştirilerinin en fazla kadınlardan gelmesi de, çalışmanın bir diğer sonucu olmuştur.

Anahtar sözcükler: Feminizm, Muhafazakar Söylem, Toplumsal Cinsiyet, Şiddet

\footnotetext{
* Assist. Prof. Dr., Sinop University, Faculty of Arts and Science, Sinop. nuriyesenelcelik@ gmail.com, https://orcid.org/0000-0001-6368-1956
} 


\section{Introduction}

The social media provides people space which relatively free and larger from their own real social relationships. Because of that, social sciences such as sociology research online society and the individuals of it. Twitter-like other social media tools are also provided and create communication and audience (Marwick \& Boyd 2010) and freedom of speech through producing identity. However, due to produce identity process, arise some problems between privacy protection and self-disclosure at the individual level (Liang et al. 2017).

The $3^{\text {rd }}$ International Women's and Justice Summit was held in Istanbul by The Women and Democracy Association (KADEM), on 23 November 2018. At this summit, President Recep Tayyip Erdogan stated the following: "Women are the integral part of the family and the locomotive of it. In our faith and culture, the family is a vital institution that lives in the common responsibility of men and women". The comments about the women's social status posted by the political supporters of the AK Party through Twitter also became apparent after these statements. Some of them claim the politicians always talk about women and others claim stated the feeling sad about the rise of employment ratio of women. According to them if a woman work, her family structure corrupts. When a video about violence against women was published from the presidential twitter account, the disagreement among the party followers became clear.

At this study, it is analysed comments posted under that video and described the differences between same political party supporters about the social position of women. By doing that, we can see some criticize about family and women and this frame provides us some imagination about being women and seems like a woman in the society which shared the same ideology. To reveal this image, we have to look at the academic studies about the social status of women and the distinction of political party programs about women.

\section{Difference of Political Ideology About Women's Role in Society}

Starting from the Greek word hysteria, which means the uterus, femininity has been interpreted as a phenomenon irrational and should be controlled (Berktay 2009, 59). The feminist theory of the 1970s established the gender notion in a liberating way and this method was highly encouraging in terms of theory and politics (Young 2009, 39-40).

The feminism that started in the 1960s against the patriarchal system by woman, has gone through three fundamental changes (Taş 2016):

1. The feminist movement has expanded to include young generations at the universal and local levels.

2. It has taken a self-critical position within itself and has tended to examine concepts such as gender, race, ethnicity, and language by starting to inscribe individual problems besides universal problems.

3. Feminist perception, have experienced the paradoxical and dramatic processes in societies formed by feminist groups and has transformed into a complex structure. Feminism, seen in three waves between the $19^{\text {th }}$ and $21^{\text {st }}$ centuries, starting from the basic demands such as women's right to vote and education, and to searching the source of inequality between the sexes, it evolved into postmodern views that did not accept only the problems of the upper, middle-class white women, but all kinds of micro-problems without any political perspectives (Taş 2016). In Turkey, “women's struggles during the late imperial period (1869-1923) were revealed and named as 'Ottoman feminism' for the first time within a feminist political discourse" (Çakır 2007, 62). These times which social gender was redesigned is based on the modernization movements of the Ottoman Empire. When the feminist ideology has taken consideration seriously as the development of women rights, the times' feminism grew up in this 
region is M. Kemal Atatürk's revolutions.

"Women's suffrage in Turkey emerged as a part of the modernization process, which was state-organized feminism supported by elite and governmental initiatives and ... Turkey is one of the first countries among the European states that gave women the right to elect and be elected.... Closure of the Islamic courts and the abolition of Islamic canon law gave way to a more secular law by the Civil Code. In the social sphere, Atatürk changed headgear and dress in 1925; he closed religious convents and dervish lodges in 1925, brought Tevhid-i Tedrisat Kanunu (law for the reunification of education) in 1924, and enacted surnames into law in 1934 by abolishing titles. In 1931, he introduced the metric system following the 1928 adoption of the international numeric systems. Legal equality between the sexes was instituted by changes and regulations between 1926 and 1934" (Erkan 2011, 1014-1020).

With the establishment of the Republic, the place of women in society started to be discussed because Atatürk is aware of the inadequacy of women's representation in society. A new era has started for women's rights. In 1926, the Civil Code was adopted, polygamy was banned, and the principle of an equal share of the inheritance was introduced for girls and boys. Women did not fight for these rights, and the founder republic offered these rights directly to women. This change, which took place legally without experiencing cultural change, has developed before the cultural change. Therefore, as the social structure modernized and changed, there emerged a need to defend legally given rights. Even though the social and economic position of women nowadays equates it with men, cultural codes have not mentally internalized this modernity. Therefore, in our country, feminism is stuck between cultural and legal values, and women's movements have fallen behind equality discourse and sexist historical perceptions have preserved themselves.

Society's views on the position of women became problematic when she began to gain her freedom and visibility. Turkey's secular political discourse runs through women, ideology, religion, and women's place in society should be discussion around this triangle. The fact that the first women's movements in the world were in France (Gönenç 2006, 64) is proof of the direct relationship between women's movements and human rights. Therefore, the process of seeking women's rights can turn into a conflict against her cultural and religious values. Another area where women fight is the economy field. The fact that women's labor is not considered as a labor force and home-based work is accepted as the natural duty of women, is originating from the perspective which is demand from the woman to spend her whole life at home and far away from the public sphere. In the Turkish political system, parties have some different approach principles about women and the place of women in society. According to Çelik (2018):

"It seems that the conservative approach has supported the woman's family life and protected her motherhood and responsibilities, such as household chores, which based upon the protection of the family. In the socialist approach, the dominant opinion is 'the obligations which are given by the capitalist society to women such as cooking, cleaning, childcare et al., should be taken over and shared by the whole society using collective possibilities'. The intervention to the business sector is a failure according to the liberal approach, incentives such as discrimination on behalf of women or tax exemption are not acceptable. It is to be observed there is a similarity between liberals and conservatives and the similarity between socialists and social democrats about this issue".

Individuals' opinions about women and their place in society are produced as a result of his/ her 
ideological, cultural and religious perceptions. It is easily can be observed from the policies produced by political parties on women, such an example conservativehas a discourse that defines women in the private sphere and at home, and emphasizes and sanctifies the role of women as a mother. While the social democratic view sees the women's political and social rights as a field of struggle, liberal understanding considers the positive discrimination for women as an injustice to men. According to Duman, in such a patriotic atmosphere when nationalist values were emphasized,

"...women's magazines appear to have a role in the construction of the ideal identity of the Turkish woman. Womanhood/ motherhood representations are drawn from a nationalist perspective in which motherhood is not questioned, but taken for granted as an indispensable identity of womanhood, following the needs of the new state. Anti-feminist, traditional male discourse characterized by negative representation of women, positive representation of men and depiction of women as other-centered and devoted. Also, women are told "how to feel" towards their husband" (Duman 2007, 90).

Therefore, the republic has attributed a political meaning to women during the foundation years and regarded her as an important part of the family, which a mechanism that produces and reproduces the founding values. Of course, Ataturk's republic is the origin of the perspective that gives women identity and visibility. Especially in the 1980s women's movement has struggled with the difficult political conditions in Turkey, they dared to move from the private sphere into the public sphere their social gender problems (Gündüz 2004). In another study, the effect on the feminist perspective 2000s in Turkey researched, the political atmosphere created by neoliberalism in Turkey, has damaged feminism in the 2000s and it has strengthened conservatives' economic structure (Coşar \& Kerestecioğlu 2017). Nowadays, it has been determined that women do not have equal conditions, especially in the field of education. "Amazingly low percentage of girls involved in the secondary education system can be explained by two objective factors: socioeconomic status of girls' families and gender discrimination" (Korchynska 2017).

Conservatism means maintaining the status quo in politics and giving cautious support to reforms (Akkaş 2014, 241). There were four kinds of conservatism occurrence in Turkey periodically (Genç \& Coşkun 2015, 28):

$\checkmark$ Kemalist conservatism

$\checkmark$ Nationalist conservatism

$\checkmark$ Religious conservatism

$\checkmark$ Nationalist - religious conservatism

In the academic literature in Turkey in recent years it has increased studies on feminism and conservatism. The reason for this is the increasingly neoliberal policies and the political preferences of conservative discourse on women. First of all, young women with headscarves cannot enter the university until 2007 and that times the Kemalist conservation discussed in more studies (Bora \& Çalışan 2007) In the following years, as conservative women became visible in the public sphere and increased economically, studies about her has increased (Gül \& Gül 2000; Ayata \& Tütüncü 2008; Chin 2010; Coşar \& Yeğenoğlu 2011; Korkut \& Eslen-Ziya 2011; Göksel 2013; Altunok 2016; Negrón-Gonzales 2016). It is seen that researches on conservative women's discourses have increased especially in the period of the Ak Party. On the other hand, the relation of conservative women's discourse with feminist discourse necessitated redefining cultural and gender roles through different sources (Ayata \& Doğangün, 2017). According to Acar and Altunok, the intermesh of neoliberal and neoconservative rationalities, 
the notion of gender equality loses its significance, leaving disadvantaged groups open to the detrimental effects of dominant power relations (2012).

This study aims to examine the reactions of an effort provide by a conservative political party to prevent violence against women. In the video, it is shown that violence against women is prevented by the state. Posted comments on Twitter for that video content analysis was applied and two different categories were determined: criticizing and supporting comments. More specifically, critical interpretations often contain conservative discourses and generally support that political party. Supporting comments advocated this video, even if they do not support the party, seen this video as a correct step and reacted to critical comments.

\section{Research Method and Analyse}

In this study, content analysis was used for twitter comments and semiotic analysis was used to analyze the related video. The reason for this dual method is to reveal the relationship between the perception of gender in the visual and the perception of the gender produced in the comments. While doing this, the hermeneutic pattern was used. The term Hermeneutic was used in the $16^{\text {th }}$ century and goes back to the Greeks. The task of interpreting and explaining God's words to people belonged to Hermes (Zimmerman, 1999). In hermeneutic Europe, a period called the romantic era has emerged and applied to humanist sciences by representatives such as linguist Humboldt, theologian Schlegel, and Boeckh, political historian Niebuhr (Bleicher, 2017). Hermeneutic is an activity to educate and express the meaning of the implicit text (Rennie, 2012). As a result, it has been a method used in discourse analysis and communication theories and social sciences through the explanation, interpretation, and clarification tasks. It should also be noted that due to the classification of twitter comments, document analysis is carried out before content analysis. "Document analysis is a systematic procedure for reviewing or evaluating documents—-both printed and electronic material" (Bowen, 2009).

In this study, examined the comments written below of a 48-second video (https://twitter.com/tcbestepe/status/1065892108702281730) showing the results of domestic violence against women and shared by the Twitter account of presidential of Turkey (https://twitter.com/tcbestepe). Since the video was published which 24 November 2018, it is commented 1416 from 24 November to 01 December. From these comments, users' answers to each other, abusive content and disinterested statements are excluded from the study. As a result, non-probability sampling is used in this study. "Non-probability sampling is that sampling procedure which does not afford any basis for estimating the probability that each item in the population has of being included in the sample" (Kothari, 2004:59). It is also known by different names such as deliberate sampling, purposive sampling, and judgment sampling. In this type of sampling, the researcher intentionally selects the items of the sample.

The video used in the study attracted reaction on social media and was especially criticized by the supporters of the ruling party. In this respect, the comments made to the video became an important data in terms of analysing the perception of women created by the differences in ideology. The 152 tweets evaluated were classified as follows:

Table 1. Numbers of Tweets

\begin{tabular}{|l|l|}
\hline Content of Tweets & Number of Tweets \\
\hline Supportive & 66 \\
\hline Critical & 86 \\
\hline TOTAL & 152 \\
\hline
\end{tabular}

a) Describing the video through semiotic analysis

According to Barthes, "in semiotics denotation and connotation are terms describing the 
relationship between the signifier and it's signified, and an analytic distinction is made between two types of signified: a denotative signified and a connotative signified. Meaning includes both denotation and connotation" (Chandler 1994). Barthes has claimed every ideological sign is either a Denotative sign system or a Connotative sign system (Essay 2018). While "denotation" means the definitional, 'literal', 'obvious' or 'common-sense' meaning of a sign, "connotation" is used to refer to the socio-cultural and identical associations such as ideological, emotional of the sign and these distinctionsare usually related to the interpreter's or researcher's class, age, gender, and ethnicity (Chandler 1994). If we analyse the video that is the subject of our study through semiotic analysis, we can interpret the twitter comments written for the video at a higher understanding level. For this, we will use Barthes' notions of the denotative sign system and connotative sign system.
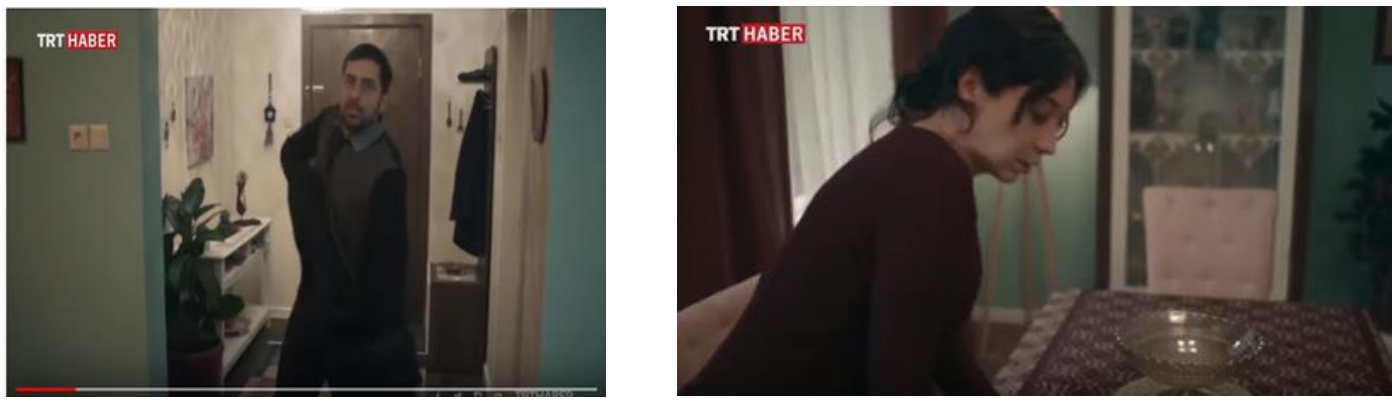

Fig. 1. The First Scene From the Video

A low-income family is seen when looking at the house's items, the clothes of men and women, and the dining table. The colours are pale and sultry. The nervous and fearful state of the woman and the angry and unhappy state of the man stand out.

Table 2. Semiotic Analysis Table

\section{Signifier}

The man comes

from outside, opens

the door and comes

upon a woman in

the way that he

intended to attack her.
Denotative sign

The man appears unhappy, strong and aggressively for no reason, and the woman appears unhappy and full of fear.

\section{Connotative sign}

The man appears unhappy, strong and aggressively for no reason, and the woman appears unhappy and full of fear. She seems weak and in need of help. The man starts screaming and attacking as soon as he enters the house. Although the woman becomes full of fear, she continues to prepare the dinner table. We see they are married from the picture of marriage in the following seconds. This unhappy married couple's daily routine has shown in unhappiness and violence conditions. It can be said that through the house and the clothes of the male and female characters, the income level of the family is medium or below the middle.

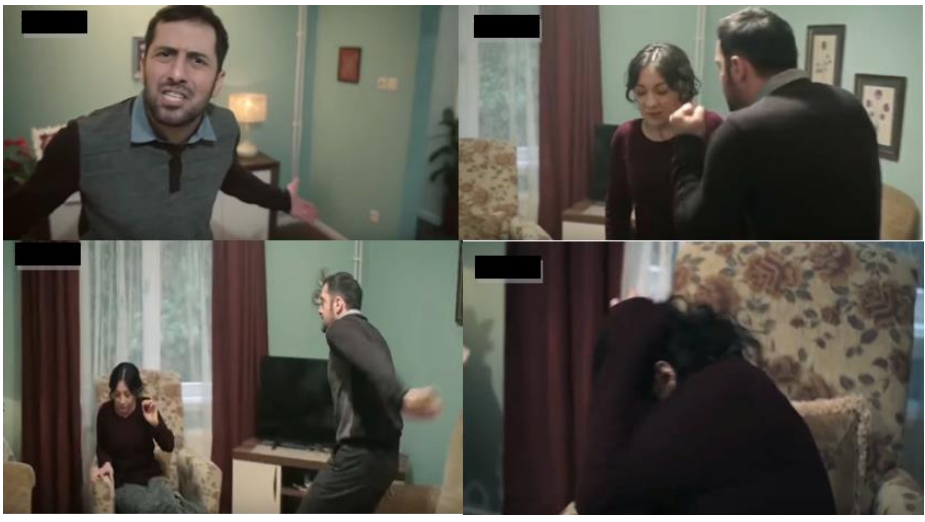

Fig. 2. The Second Scene From Video 
In Fig. 2, we have the opportunity to see other items of the house, such as armchairs, curtains, television. The low-income level of the family is still remarkable. The audience feels like the first witness of the violent case and even the man shouting to the audience somewhere. The witnesses of the woman's inability to protect herself are the audience

Table 3. Semiotic Analysis Table

\section{Signifier}

The woman tries to protect her head with hands, snuggles into a couch and stays there throughout the rest of the video. The man is seen to present aggressive behaviour with his body language around the room constantly.

\section{Denotative sign}

The woman tries to protect herself with the fear of the man's aggressive behaviours. The man does not touch the woman physically throughout the video.
The woman seems helpless, but because of the calmness of her behaviour, it is clear that this violence scene is not the first time for her. The man is constantly yelling her, while the household items are broken. One of the broken objects is the photographs of their marriage, and the breakage of this picture points to the ruined relationship in their marriage. The woman must appear physically weak and lonely, because the protective role of the state will replace the loneliness of woman.

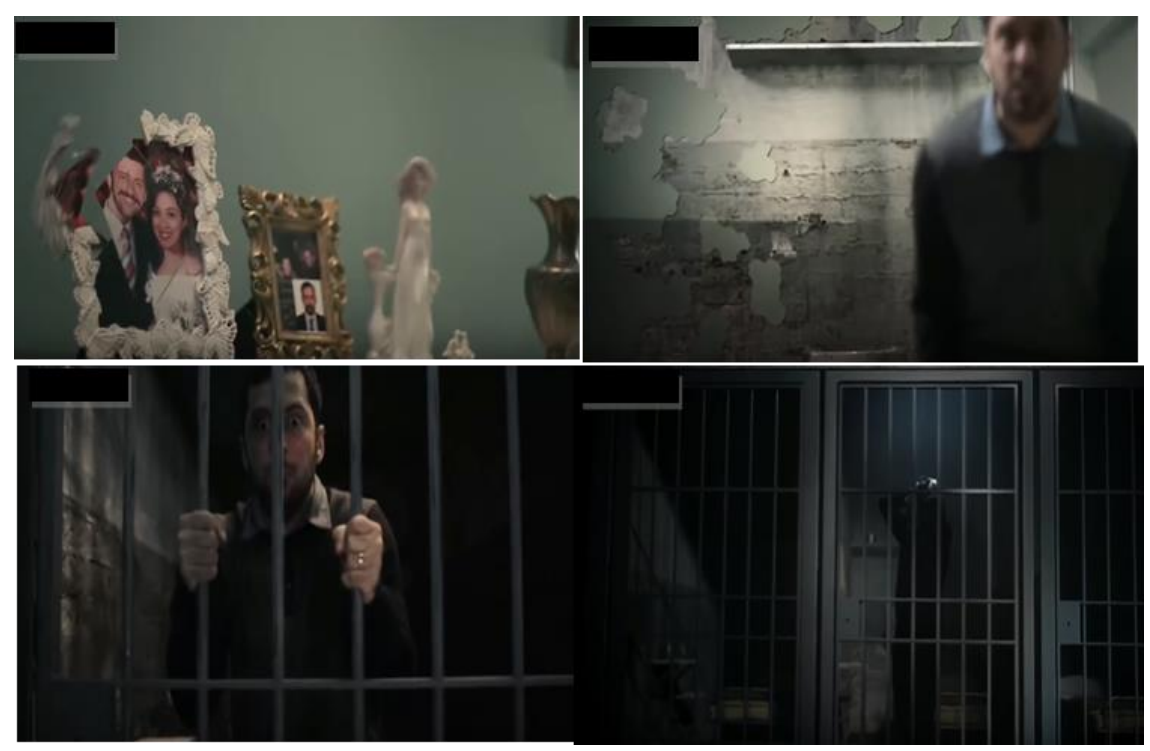

Fig. 3. The Third Scene From Video

At this stage, we are witnessing the walls of the house collapsing and turning into a black, dark cell. The video has an 8724 retweet and 32,511 like. A total of the video is 48 seconds and it starts with a woman seen at home. The voice speaking throughout the video, says in a way confident and patronage:

"The violence at the home is not legitimate, no matter under what circumstances.

There is no excuse or forgiveness of violence against women. According to our laws, if the perpetrator, acts contrary to the precautionary decision taken, without investigation and trial, immediately, without being fined, directly he will sentence imprisonment. The violence at home ends in prison".

In the video, there is a man seen as aggressive and rude husband and a woman seen in a miserably way. She needs protection and this support provide by the government. The purpose of this video is a threatening the men violent against women and supporting the woman needs protection. 
Table 4. Semiotic Analysis Table

Signifier

The furniture and walls of the house are broken and the house becomes a prison cell. The man finds himself behind prison bars.
Denotative sign Despite he does not physically harm the woman, the man breaks down the households and as his violence increases, he condemns himself to prison.

\section{Connotative sign}

While the house turned into a prison cell, the idea that the house shown at the beginning of the video refers to a prison cell for the woman comes to mind. The woman is no longer helpless and in need of protection because the state will protect her. However, the woman will continue to require protection of someone or something; she will only have changed her guardian. Even in the last seconds, he found himself in prison; he appears with a violent and angry face. The man's house, which turned into a prison, has become an escape space where the walls have been destroyed for the woman, and in the last scene, there is no woman.

Nevertheless, for some Ak Party supportive, the video seen as a destroying perspective for a family structure and according to other supportive it is a great message because it's Erdogan's message. In addition, for some who does not support the Ak Party, it is great development for conservatives about their gender policies. The main purpose of this study is to explain and understand these messages arising from tweet comments under the video. In the next section, content analysis was applied to Tweet comments.

\section{b) Content Analyse of Tweets Comments}

In this study, the tweeter comments that written during the seven-day period from 24 November 2018, which the date of publication of the video to 1 December 2019, were examined. The 3rd International Women's and Justice Summit were held in Istanbul by The Women and Democracy Association (KADEM), on 23 November 2018. At this summit, President Recep Tayyip Erdogan mentioned the importance of women in the family and the next day, the video prepared to prevent violence against women was uploaded to the tweeter account of the Presidency. After that, the video was retweeted 8724 times and was liked 32,511 times and is commented 1416 times in seven days.

There are generally two main approaches in tweets: supporters and critics. The abundance of critical comments led the video supporters to respond to these negative comments. Negative comments made on tweeter attracted attention and it was observed that the discourses in these interpretations have some common points. One of the aims of this study is to reveal these common points and questioning the ideological structure under it.

Table 5. Content Analysis of Supportive Tweets

\begin{tabular}{|l|l|}
\hline The reasons of support & Frequency \\
\hline Respond to negative comments. & 43 \\
\hline If AK Party did this, then it is ok for me. & 2 \\
\hline Everyone should stop violence against women regardless of their ideology. & 21 \\
\hline Total & 66 \\
\hline
\end{tabular}

In supportive comments, it is clear that there is common sense about a partnership for stopping the violence against women regardless of the distinction of ideologies:

"Perfect work. I read some mentions written by women. They must be living in mind eclipse. If we let them, they say "men can violent a woman as he wants" for just to be against feminism. What a pity...".

“... violence is not only assaulted physically. Restricting women's economic freedom, depriving her friends and loved ones, restricting her behaviour arbitrarily, and any form of forced action means violence". 
The common sense about the violence against women is a sign of the great collective consciousness in the society. That collectiveness sometimes protects a woman in the streets when assaulted by her husband or boyfriend or sometimes protect the green space in the city they living in or sometimes build a democratic and secular society against all kind of difficult circumstances. In supportive comments, there is the same reaction to critical tweets. All the supportive feel angry about the criticizer and their comments about women's and men's social status in society.

"I started to read these tweets written for video in a very nice pub in London when I finished, I felt like I live in Kabul, Afghanistan".

"Those who are disturbed by this video are probably have been made violence against any women".

"I am a man. The respect you need, you cannot achieve through the assault a woman. You complain about alimony but your wife does not work because you did not let her. When you divorce, she needs your money for living".

"Those who are disturbed by this video are criminals of violence".

"In this age, is there a person who does not accept socially and economically equality between men and women and accept normal the violence regardless of the cause, against women or any species?".

"Is it so important to beat your wife, why would you criticize the video so much?"

"Everyone who says that be against violence to women is a feminist according to you. All of them are trying to disrupt the structure of the Turkish family and they're made all men miserable".

In supportive comments, there is common discourse: to give a response to critical tweets. To understand that common ground we have to analysis critical tweets discourse

Table 6. Content Analysis of Critical Tweets

\begin{tabular}{|l|c|}
\hline The reasons of criticism & Frequency \\
\hline The video contains misandry and all men are accused of being violent and fit of temper. & 24 \\
\hline $\begin{array}{l}\text { The fact that the statement of women is the basic proof of violence accuses is wrong, it } \\
\text { is one-sided. }\end{array}$ & 8 \\
\hline Law No. 6284 gives indefinite alimony to women, men are being victimized. & 16 \\
\hline $\begin{array}{l}\text { Violence has no gender (they gave examples of women who commit violence against } \\
\text { own children) }\end{array}$ & 5 \\
\hline $\begin{array}{l}\text { The reasons for violence are poverty, drinking, gambling, interest, and credits (banking } \\
\text { sector). }\end{array}$ & 6 \\
\hline Feminism harms the ideology of the AK party & 18 \\
\hline $\begin{array}{l}\text { Feminism harms the integrity of the family, leading the singles to think the marriage not } \\
\text { good and the video harms the image of the family and is a bad example for the singles. }\end{array}$ & 86 \\
\hline TOTAL & \\
\hline
\end{tabular}

There is an important discourse underlying these critical tweets: the ideology you support may not say true always and you have the right to criticize the party you voted. This is an important result of the democratic system in Turkey.

"What a pity, even the chief who we voted, shares video that insults the Turkish nation and humiliating the Turkish men. Shame on we voted. The Netherland funded Turkish nation's demolishing policy continues rapidly”.

"Fortunately, there was no law no. 6284 in the time of Adam and Eve; Thank God we could not be here now". 
"To publish a humiliating video that intended men who got up early in the morning and work to earn the money for bread to his family is a shame and sin at least".

"Mr. President, while legislating that kind of laws that affect our family structures, let us ensure that they comply with our national, spiritual and especially religious values and our social codes and that they are fair and applicable. May Allah help you".

Law No. 6284 on the Protection of the Family and the Prevention of Violence against Women was adopted on $8 / 3 / 2012$. This law was made to prevent violence against women, children, family members, and this law criticized because of women's declaration is accepted as an essential proof. On the other hand, considering the reasons for criticism, it is possible to see the identity of women in conservative discourse. Women, as an important element for the family, are accepted as an integral part of the family, on the contrary to an individual and singular identity. This perception is a reference to the holy reaction that the being family and mother has found in society. Being a mother is an important and necessary nature of identity in Turkey and there are important studies about motherhood on media (Sever 2015, Bal 2014, Türkdoğan 2013, Gürçayir Teke 2014, Tuğrul 2018). So that, not being mother may even cause women to be underrated from time to time by people around. For instance, a newspaper column which about denying motherhood was highly criticized on twitter and according to the author (Özcan 2016):

"Do not force a woman to talk about having children. ... Giving birth is not a virtue. Since this is not a virtue, the woman who does not give birth is not uncompleted. Many women live in the worlds who say that "fortunately I do not give birth" because of do not give up their desires and dreams and do not have to reading fairy tales at night or going to child birthdays or pay the tuition".

Feminism is another common point of criticism. According to some users, feminism is a concept that corrupts family values and overvalues the women, contains discourses that are opposed to conservative ideology.

"We cannot find the opportunity to think about what does Islam give women and which rights gives her, because of thinking constantly about what Europe and the West say and demands. We made slaves to the bosses the ladies who train the conquerors. While she is a sultan in her home, she became a slave in her work".

"May my Lord protect our country from friendly-looking people who have settled near the chief. Feminism vampires have their teeth in the heart of this country. The end of the country is not good at all. May Allah help this glorious nation".

"Because of the laws you made with the new so-called Muslim feminists, the dynamites you have placed in the roots of the family will explode soon. then there will be no one to close to the dungeons. Women you deified cannot save society".

Yet another criticism is that the man in the video is presented as a male image that plays an aggressive and humiliating role. In this video, the female image is weak, helpless and the male image displays an angry, aggressive and unstoppable social role. The understanding that always positioning the male image as strong, protective, and authoritative and imposes a social role to men similar way to women, created this powerful and an intolerable man image.

"As a man, I condemn those who prepare this video. I and the men around me are not like that. but according to the mentality that prepares 
this video, all men are showing as violent. What a pity! Keep showing men that way!"

\begin{abstract}
"Why there is so much misandry?"
"Women and men are very respectable and valid parts of the family institution. we need to protect and strengthen the family ties. On the contrary, the policies produced are harming the family image. Let's keep the family institution alive and strong".

"The man is the father, the man is the mainstay of the family, the man is human, and the man is not the enemy. Violence against any living thing is unacceptable".

"According to the statistics, women use more violence against their children than men. Let's get rid of prejudice and stereotypes".

"The video raises the misandry and misogynistic".

"In the continuation of this video, you have to show the unfaithful women, immorality and rudeness girls and their caprices that make people crazy".
\end{abstract}

"Why there are men in the role of villains? Don't you see the abuse of law no 6284?".

Obviously, committing violence is not a feature of any race or genre. However, statistical data shows that men's violence against women is higher than women's violence against men.In the violence and sexual harassment prosecutions, judging on the basis of a woman's declaration is another subject of criticism:

"We are against the violence of women ... If there are a report and witness of violence, then the man should go to prison. But what does it mean that women's statement is essential to proof? When a woman gets angry with her husband, she can easily declare the wrong information and get rid of him".

In addition, it is another criticism subject that the long of the marriage is not taken into consideration in determination of the alimony. Again, referring to Law No. 6284, indefinitely alimony is criticized and it is claimed that the woman does not married because of she would lose alimony when she married her next relationship. The point that should not be unnoticed is alimony has a sociological meaning beyond contributing to the livelihood of women. In this society, the price of the social and status changes experienced by the divorced woman is alimony. Another source of criticism is the claim that video harms singles' thoughts about marriage.

"The example of a good family is so few, unfortunately. Therefore, I was sad, surprised, and angry when the film represented an evil family image and this representation was made by the state. We need good family samples, much more of them".

"We cannot serve the family by making our men worthless. to show the violence against women, a much more natural, accurate video, a happy family home should be shown".

"Did anyone ever think of family integrity among those who made this video? Officially in video, a male has shown as perpetrator of violence. This video does not stop domestic violence, nor do the laws you made protect women. Look at the issue from the perspective of justice, not from the feminist perspective”. 
"You made people humanist and feminist so that society is damaged. You're talking about still more prison. Unless you raise people in the Islamic way, this society will get worse. In the times of Islam, the lady had value, the man had value. This society is in need of Islam".

According to some users, violence is caused by economic inadequacies and unemployment. Being economically inadequate and unemployment is regarded as an insulting situation for men in society.

"Without money, there is no peace, without peace, man became under nervous pressure and violence becomes inevitable".

Critical interpretations focus on these subjects: the single-charge accusation of men, the images of men and women, the evil representation of marriage, feminist discourses that harm the institution of marriage, and the economic sources of violence. Critical tweets are warning the party administration against feminist and humanist views, even though they have voted for that political party.

\section{Conclusion}

In the video, which aims to prevent violence against women shared by the Presidency, women experience feelings of fear, loneliness, and helplessness. Contrary to the criticism, this video is directly related to postmodern feminism. Accordingly, this video is an attempt to overcome violence and helplessness with an understanding that emphasizes the differences between women and the discrimination that women are exposed in their daily individual experiences, without any ideological belonging, without remembering any political formation, with a postmodern sense of identity. Defending the liberation of women from violence is not a privilege of any political view, and it is one of the most fundamental tasks of the state to defend every woman's rights as an individual. In this sense, it is the laws that operate based on the statement of the woman will save the woman in the video from her desperation. However, another mechanism that will protect women is the elimination of cultural and social conditions that create violence through education.

Therefore, critics of the video essentially criticize the kind of identity of a woman. This female identity is an active subject who tries to solve her violence problem exposed and by doing that she applies the laws and hence the public sphere and also active individual determines the continuity of the family according to her lifestyle. The notion of the sanctity of the family, which is emphasized in most of the criticisms, is the result of an attempt to create a passive identity that demands that the woman first take on the continuity of her family regardless of what happens.

The video does not develop any political discourse, but rather it says a woman is not alone and also it creates an individual identity for her and tries to reconstruct a woman's position in the family. The man was warned about imposing sanctions through the state because of his behaviour towards women. This video, which tells the woman that she is not alone, does not harm the political identity of the AK Party or the Presidency or any political party. Feminism is an umbrella that protects also conservative women. Feminism does not harm the family and the sanctity of the family; on the contrary, it establishes an equal marriage and contributes to the emergence of healthy individuals and the growth of healthy children who witness this ambiance. Women who do not develop their identities and who are imposing the violence cannot carry forward the human life conditions to their children when they become mothers. As a result, violence against women can only be solved by law and by changes in social patterns. 


\section{REFERENCES}

Acar F. \& Altunok G. (2013). "The 'politics of intimate' at the intersection of neo-liberalism and neoconservatism in contemporary Turkey”. In Women's Studies International Forum 41 (2013) 14-23.

Akkaş H. H. (2014). "Conservative political thought in the history of Turkish modernization". Journal of Social Sciences 16/1 (2014) 241-254.

Altunok G. (2016). "Neo-conservatism, sovereign power and bio-power: Female subjectivity in contemporary Turkey". Research and Policy on Turkey 1/2 (2016) 132-146.

Ayata A. G. \& Tütüncü F. (2008). "Party Politics of the AKP (2002-2007) and the Predicaments of Women at the Intersection of the Westernist, Islamist and Feminist Discourses in Turkey". British Journal of Middle Eastern Studies 35/3 (2008) 363-384.

Bal S. (2014). "The Ageless Face of Ads: Magnificent Motherhood, Example of Mother's Day Ads". Ilef Journal 1/2 (2014) 59-85.

Berktay F. (2009). “An Important Field of Feminist Theory: Sexuality”. Cogito 2887, 58.

Bleicher, J. (2017). Contemporary Hermeneutics: Hermeneutics as Method, Philosophy and Critique (Vol. 2), Routledge Publications 2017.

Bora A. \& Çalışkan K. (2007). "What is Under a Headscarf? Neo-Islamist vs. Kemalist Conservatism in Turkey”. The Arab Studies Journal 15/2:1 (2007) 140-155.

Bowen G. A. (2009). "Document Analysis as a Qualitative Research Method". Qualitative Research Journal 9/2 (2009) 27.

Çakır S. (2007). "Feminism and Feminist History Writing in Turkey: The Discovery of Ottoman Feminism". Aspasia 1 (2007) 61-83.

Çelik N. (2018). "The Social Policy Vision of Political Parties in Modern Turkey". Mediterranean Journal of Humanities VIII/2 (2018) 251-264.

Chandler D. (1994). Semiotics: The Basics (3rd Edition). Routledge Publish, http://www.aber.ac.uk/media/ Documents/S4B/ [23.11.2019].

Chin R. (2010). "Turkish women, West German feminists, and the gendered discourse on Muslim cultural difference". Public Culture 22/3 (2010) 557-581.

Coşar S. \& Yeğenoğlu M. (2011). "New grounds for patriarchy in Turkey? Gender policy in the age of AKP". South European Society and Politics 16/4 (2011) 555-573.

Duman D. (2007). “Gender Politics in Turkey and the Role of Women's Magazines: A Critical Outlook on the Early Republican Era". Political Linguistics Conference, Waresaw University 13-15 September (2007) 75-92.

Erkan A. Ü. (2011). "The Formation of Feminist Identity: Feminism in The 1930's Turkey and Britain". Kastamonu Education Journal 19/3 (2011) 1013-1028.

Essays UK. (November 2018). "Roland Barthesand His Semiotic Theory". Retrieved from https://www.ukessays.com/essays/cultural-studies/roland-barthes-and-his-semiotic-theory.php?vref=1 [23.11.2019].

Genç E. \& Coşkun T. (2015). "Some Cases of Conservatism the Conservatism of Turkey". Journal of the Faculty of Economics and Administrative Sciences 8/1 (2015) 27-40.

Gezer T. Y. (2018). "Religious Women's Perception of Motherhood: A Comparative Analysis of Jam Blog and Muslim Mothers Blog" Fe Journal 10/2 (2018) 71-84.

Göksel İ. (2013). "Female labor force participation in Turkey: The role of conservatism". In Women's Studies International Forum 41 (2013) 45-54.

Gönenç A. Y. (2006). “Fransa'da ve Türkiye'de Kadin Hareketleri”. Istanbul University Faculty of Communication Journal 27 (2006) 63-84.

Gül S. S. \& Gül H. (2000). "The question of women in Islamic revivalism in Turkey: A review of the Islamic press". Current Sociology 48/2 (2000) 1-26.

Gündüz Z. Y. (2004). “The Women's Movement in Turkey: From Tanzimat towards European Union Membership 1. Perceptions”. Journal of International Affairs 9/3 (2004) 115-134.

Güneş-Ayata A. \& Doğangün G. (2017). "Gender politics of the AKP: Restoration of a religioconservative gender climate”. Journal of Balkan and Near Eastern Studies 19/6 (2017) 610-627.

Gürçayir Teke S. (2014). "A Netnographic Analysis of Transforming Motherhood: Blogger Mothers". National Folklore 26/103 (2914) 32-47.

Korchynska N. (2017). "The Role of Gender Policy in Turkish Vet System”. Comparative Professional Pedagogy 7/2 (2017) 63-68. 
Korkut U. \& Eslen-Ziya H. (2011). "The impact of conservative discourses in family policies, population politics, and gender rights in Poland and Turkey". Social politics 18/3 (2011) 387-418.

Kothari C. R. (2004). Research Methodology: Methods and Techniques. New Age International Publishers 2004.

Liang H. Shen F. \& Fu K. W. (2017). "Privacy protection and self-disclosure across societies: A study of global Twitter users". New Media \&Society $19 / 9$ (2017) 1476-1497.

Marwick A. E. \& Boyd D. (2011). "I tweet honestly, I tweet passionately: Twitter users, context collapse, and the imagined audience". New Media \& Society 13/1 (2011) 114-133.

Negrón-Gonzales M. (2016). "The feminist movement during the AKP era in Turkey: challenges and opportunities". Middle Eastern Studies 52/2 (2016) 198-214.

Özcan P. (2016). Hürriyet, Do you regret about you've baby? https://hthayat.haberturk.com/yazarlar/ perihan-ozcan/1037362-peki-sen-cocuk-yaptigina-pisman-misin (24.11.2019).

Rennie, D. L. (2012). "Qualitative Research as Methodical Hermeneutics". Psychological Methods 17/3 (2012) 385.

Sever M. (2015). "Femininity, motherhood, voluntary childlessness: Femininity or Motherhood by Elisabeth Badinter?, Tina Miller's Sense of Motherhood: Myths and experiences and a comparative reading study on Corinne Maier's No Kid". Fe Journal 7/2 (2015) 72-86.

Simten C. \& İnci Ö. K. (2017). "Feminist Politics in Contemporary Turkey: Neoliberal Attacks, Feminist Claims to the Public". Journal of Women, Politics \& Policy 38/2 (2017) 151-174, DOI: 10.1080/1554477X.2016.1198656

Taş G. (2016). “A General Evaluation on Feminism: Conceptual Analysis, Transformation of Historical Processes". The Academic Elegance 3/5 (2005) 163-175.

Young I. M. (2009). "Gender Against the Living Body: Thoughts on Social Structure and Subjectivity". Trans. Rüya Kalıntaş, Cogito 58 (2009) 39-56.

Zimmerman, J. A. (1999). Liturgy and Hermeneutics. Liturgical Press Publications 1999. 